\title{
Sludge Composition for Each Tank and DWPF Feed Batches
}

by

J. R. Fowler

E. I. du Pont de Nemours and Company

Savannah River Site

Aiken, South Carolina 29808

This paper was prepared in connection with work done under the above contract number with the U.S. Department of Energy. By acceptance of this paper, the publisher and/or recipient acknowledges the U.S. Government's right to retain a nonexclusive, royalty-free license in and to any copyright covering this paper, along with the right to reproduce and to authorize others to reproduce all or part of the copyrighted paper. 


\section{DISCLAIMER}

This report was prepared as an account of work sponsored by an agency of the United States Government. Neither the United.States Government nor any agency thereof, nor any of their employees, makes any warranty, express or implied, or assumes any legal liability or responsibility for the accuracy, completeness, or usefulness of any information, apparatus, product, or process disclosed, or represents that its use would not infringe privately owned rights. Reference herein to any specific commercial product, process, or service by trade name, trademark, manufacturer, or otherwise does not necessarily constitute or imply its endorsement, recommendation, or favoring by the United States Government or any agency thereof. The views and opinions of authors expressed herein do not necessarily state or reflect those of the United States Government or any agency thereof.

This report has been reproduced directly from the best available copy.

Available to DOE and DOE contractors from the Office of Scientific and Technical Information, P.O. Box 62, Oak Ridge, TN 37831; prices available from (615) 576-8401.

Available to the public from the National Technical Information Service, U.S. Department of Commerce, 5285 Port Royal Road, Springfield, VA 22161. 


\section{DISCLAIMER}

Portions of this document may be illegible electronic image products. Images are produced from the best available original document. 


\section{Q12 " "WFORMATION ONLS"}

- ${ }^{2}$

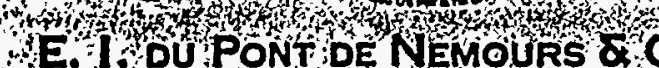

E. 1 OU PONTDE NEMOURS \& COMPANY

: 1,2 how

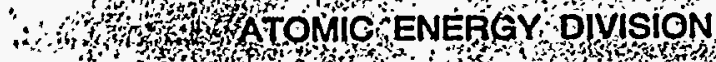

1: WOSAVANNAH RIVEA LABORATORY

AIKEN, SOUTH CAROLINA 298080001

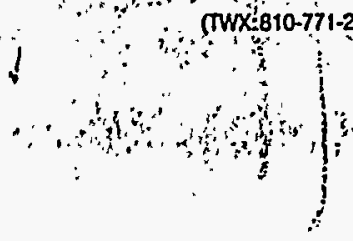

(a)

wo

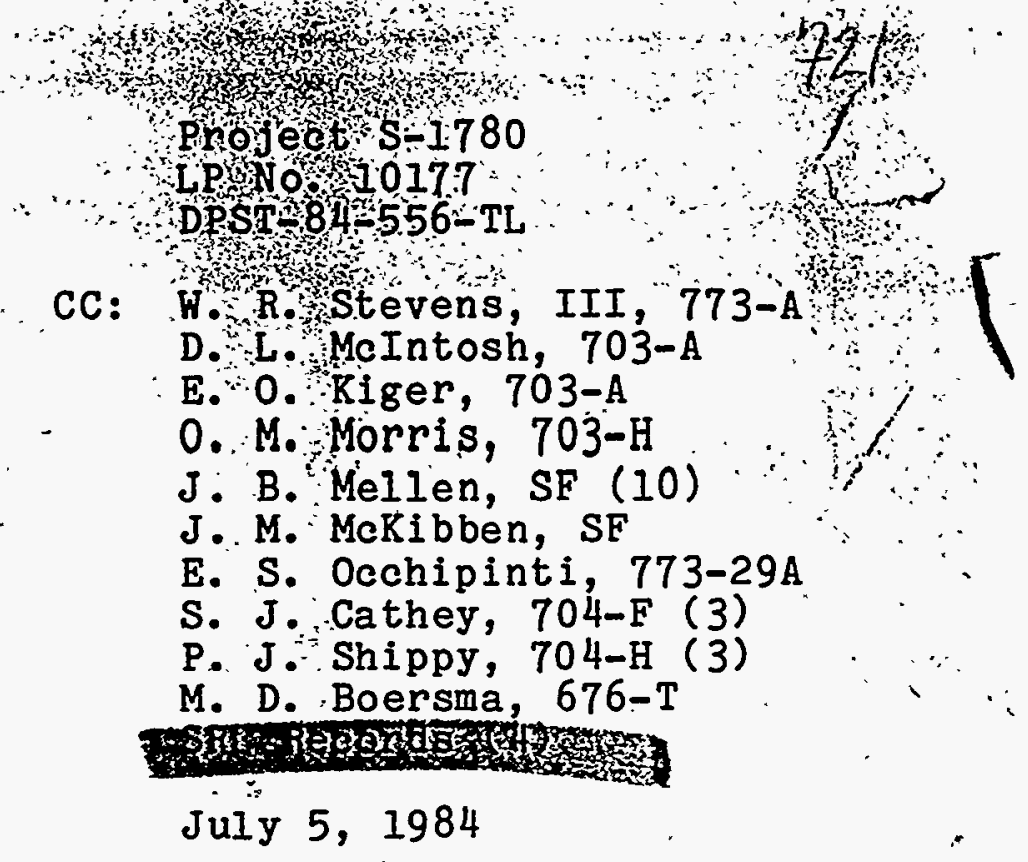

J. T. GRANAGHAN, PLANT MANAGER

SAVANNAH RIVER PLANT

ATTENTION: D. C. NICHOLS (5)

Projedt- S-1780

LP:No 10177

DPST $84 \div 556-T L$

H. R. Stevens, III, 773-A

McIntosh, 703-A

E. O. Kiger, 703-A

. M. Morris, 703-H

J. B. Mellen, SF (10)

S. J. Cathey, 704-F

P. J Shippy, 704-H

M. D. Boersma, 676-T

JuIy 5,1984

\section{SLUDGE COMPOSITION FOR EACH TANK AND DWPF FEED BATCHES}

Attached is a sumary of the chemical composition of the sludge on

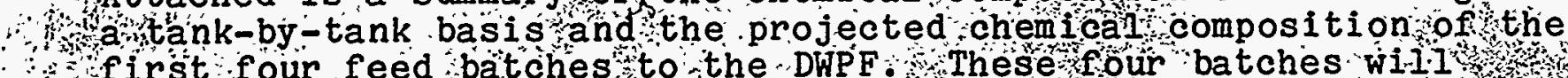

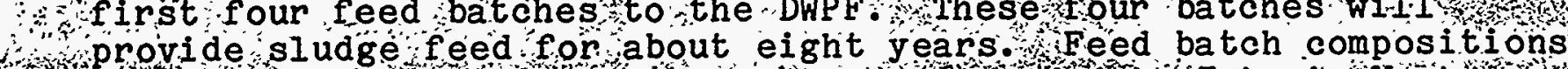

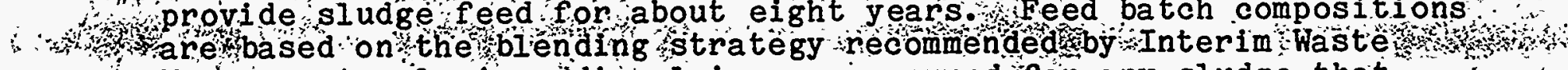

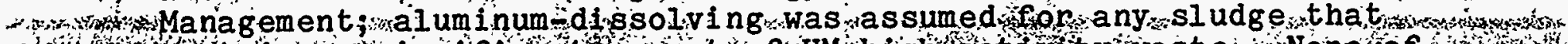

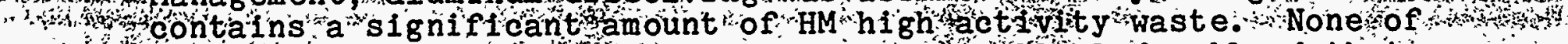
Wthese batches differsigreatly from the overalitsidudge blend that

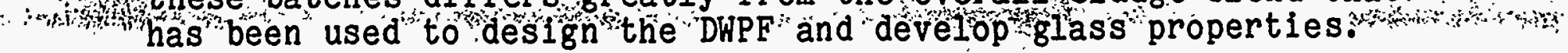

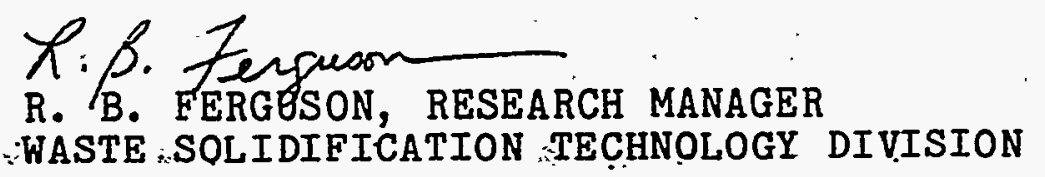

JRF : tks

Att 
TECHNICAL DIVISION

SAVANNAH RIVER LABORATORY
DPST $-84-55 \dot{6}$

CC: W. R. Stevens, III, 773-A

G. W. Wilds, 773-A

E. L. Albenesius, 77.3-A

R. B. Ferguson, 773-A

M. A. Ebra, 773-A (3)

M. J. Plodinec, 773-A (3)

D. C. Witt, 676-1T

D. G. Kilpatrick, 676-1T

R. E. Edwards, 704-T

L. F. Landon, 704-T

B. G. Kitchen, 773-29A

W. R. McDonnell, 773-4IA

TKS File

June 11, 1984

$\underline{M} \underline{\mathrm{E}} \underline{\mathrm{M}} \underline{\mathrm{O}} \underline{\mathrm{R}} \underline{\mathrm{A}} \underline{\mathrm{N}} \underline{\mathrm{D}} \underline{\mathrm{U}} \underline{\mathrm{M}}$

TO: M. D. BOERSMA, 676-T

FROM: J. R. FOWLER, 704-T (2)

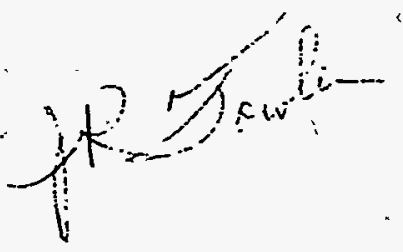

SLUDGE COMPOSITION FOR EACH TANK AND DWPF FEED BATCHES.

\section{Summary}

The chemical compositions of sludge on a tank-by-tank basis and in the proposed first four batches of feed to the Defense Waste processing Facility (DWPF) have been calculated. Chemical compositions of major types of waste, based on analytical and theoretical work, were previously estimated.1,2 These were used, along with tank histories and current inventories 3 to calculate tank compositions. These in turn were used, along with blending strategies proposed by Interim Waste Management (WMO/WMT) 4 , to calculate the chemical compositions of the first four batches of sludge feed for the DWPF. These four batches will provide about eight years of feed for the DWPF. In all cases, the weight percents of dry solids were calculated by assuming 1.95 lbs of insoluble solids are present in a gallon of settled sludge. 
M. D. BOERSMA - 2 - DPST-84-556

The chemical compositions of the four proposed batches do not differ greatly from the blended waste composition that has served as the basis for DWPF design and for waste glass product evaluations. These batches should be well-suited for processing in the DWPF without altering the process as now designed.

Based on the blending strategy and the age of the sludge in inventory, the minimum age of the sludge fed through 1996 would be approximately 10 years at the time of processing through the DWPF. Most of the sludge would be at least $20^{\circ}$ years old at the time of processing. Because of the age of these batches, radionuclide concentration and shielding will be of minimal concern until after these batches are processed. The age and composition of two additional batches will be provided by WMO/WMT to establish if radionuclide concentration and shielding will be of concern after the older sludge inventory is depleted.

Mercury is present in all sludge types analyzed to date and is also present in salt. Preparing a sludge blend free of mercury for the initial batch to be fed to the DWPF is probably not feasible.

Details

I. Tank-by-Tank Chemical Composition

A. Waste Inventory and Composition.

Based on tank histories, Purex HAW and Purex LAW sludge are segregated in F-Area waste tanks except for Tank 7F. Tank $7 F$ has been used as a receiver for LAW. The Purex HAW that was removed from Tanks $1 F, 2 F$, and $3 F$ to enable salt storage was placed in Tank $7 F$. Based on its history, Tank $7 F$ in F Area contains a blend of Purex HAW, Purex LAW, sand and coal. Sludge volumes by type for F-Area waste tanks are shown in Table $I$.

In $\mathrm{H}$ Area, several tanks contain various blends of Purex HAW, Purex LAW, HM HAW, and HM LAW because two processes (Purex and HM) have been run in the H-Area Canyon. Frame waste from Pu-238 production is combined wi.th HM LAW waste. Several sludge transfers between older tanks havé also been done during interim waste manágement operations. Segregation of HM. HAW and HM LAW sludge has been maintained in the newer tanks. Sludge volumes by type for H-Area waste tanks are shown in Table II. 
M. D. BOERSMA - $3-\quad$ DPST-84-556

B. Mercury Content of Sludge.

Available results for mercury from specific sludge samples are shown in Table III for individual tanks. F-Area waste is significantly lower in mercury than H-Area waste, but the waste is not free of mercury.

\section{Tanks Containing One Type of Sludge}

Tanks containing only one type of sludge are summarized below by waste type. Several tanks also contain sludge solids from other operations (zeolite from CRC, sludge from 100 Areas disassembly basins). These tanks are shown separately.

Purex HAW: IF, 2F, 3F, 4F, 5F, 6F, 9H, 10H, 33F, 34F.

Purex LAW: $8 \mathrm{~F}, 17 \mathrm{~F} ; 18 \mathrm{~F}, 19 \mathrm{~F}, 20 \mathrm{~F}, 47 \mathrm{~F}$.

HM HAW: $32 \mathrm{H}, 35 \mathrm{H}, 39 \mathrm{H}$.

HM LAW: $21 \mathrm{H}, 22 \mathrm{H}, 43 \mathrm{H}$.

Zeolite: $19 \mathrm{~F}, 27 \mathrm{~F}, 24 \mathrm{H}, 42 \mathrm{H}$.

100 Areas Sludge: $47 \mathrm{~F}$.

The chemical composition of each waste type is shown in Table IV. Zeolite, coal and sand - components in specific tanks only - have been eliminated from the LAW compositions to provide adjusted Purex LAW and HM LAW compositions. The composition shown for HM HAW does not reflect aluminum dissolving.

D. Tank-by-Tank Compositions

Calculated composition of sludges in tanks containing mixtures of several waste types are shown in Tables $\mathrm{V}-1$ through $\mathrm{V}-3$. These compositions include zeolite, sand and coal where appropriate.

II. Composition of DWPF Feed Batches:

A. Proposed Blending Strategy

The blending strategy proposed by WMO/WMT is summarized in Table VI. The volumes and compositions shown assume that the zeolite presently in Tank $24 \mathrm{H}$ will be split between Tank $13 \mathrm{H}$ and Tank $43 \mathrm{H}$. The zeolite in Tank 19F will be transferred to Tank 18F. These transfers will occur before DWPF feed preparation begins. 
M. D. BOERSMA - $-4-\quad$ DPST $-84-556$

All sludges containing significant amounts of HM HAW will be aluminum dissolved. These sludges are presently contained in Tanks $11 \mathrm{H}, 12 \mathrm{H}$, $13 \mathrm{H}, 14 \mathrm{H}, 15 \mathrm{H}, 32 \mathrm{H}, 35 \mathrm{H}$, and $39 \mathrm{H}$. The sludge in Tank $42 \mathrm{H}$ has already been aluminum dissolved.

Residual volume of sludge after aluminum dissolving is assumed to be $50 \%$ of the present volume in inventory based on experience from the in-tank demonstration of aluminum dissolving. Because of the significant quantity of other sludge types in Tank 13H, residual volume of sludge from Tank $13 \mathrm{H}$ is assumed to be $75 \%$ of the present inventory. These assumptions were used to estimate the volumes of the four batches to be fed to the DWPF.

\section{B. Composition of DWPF Feed Batches}

The major components of the four batches to be fed to the DWPF are shown in Table VII. For comparison, the composition of the overall sludge blend presently used in the flowsheet is also shown. These batch compositions do not differ widely from the overall sludge blend and the variations from the blend should have minimal impact on the design and operation of the DWPF. Aluminum dissolving of HM HAW sludges listed in the previous section is reflected in these compositions. A complete listing of the components in each batch is available from $J$. R. Fowler, if needed.

III. Quality Assurance and Quality of Data

Results presented here are based on the best available data at the time of writing. The purpose of this document is to provide guidance for sludge processing strategy in the tank farm. Results shown here should not be construed to yield an exact description of any sludge from the tank farm because of the variable nature of waste handing and simplifying assumptions used in these calculations. Data presented is of sufficient accuracy for planning purposes, but it will not substitute for actual analyses of various sludge samples during sludge removal and blending operations.

Sludge volume data rather than weight data is available from Tank Farm records. Consequently, variation of the weight of sludge solids in a specified volume can influence calculations significantly. Results from calculations shown here are strongly dependent on two simplifying assumptions:

- 1.95 lbs sludge solids/gallon

- $50 \%$ reduction in. sludge volume during aluminum dissolving. 
M. D. BOERSMA

$$
\text { - } 5 \text { - DPST-84-556 }
$$

The volume of 1.95 lbs/gallon has been used in all sludge composition calculations associated with the Tank Farm and DWPF. - Experimentally, settled sludge solids ranging from 1.5 to 2.8 lbs/gallon have been observed in samples from the Tank Farm.

In the in-tank demonstration of aluminum dissolving, residual sludge after treatment settled to approximately half the original volume of sludge that was treated. Accordingly, $50 \%$ of the volume of sludge to be aluminum dissolved was used to estimate batch sizes except for Tank 13H. Only 25\% volume reduction was assumed for $13 \mathrm{H}$ because a significant fraction of this sludge does not contain a high concentration of aluminum hydroxide.

References

1. R. E. Eibling and J. R. Fowler; "Updated Waste Composition at the Savannah River Plant", DPST-83-313, February 16, 1983.

2. R. E. Eibling and J. R. Fowler, "Waste Composition at the' Savannah River Plant", DPST-82-897, October 4, 1982.

3. "Monthly Report - February 1984; Waste Management Technology", March' 5, 1984.

4. S. J. Cathey and P. J. Shippey, private communications. 
TABLE I

SLUDGE IN F-AREA WASTE TANKS

WASTE VOLUME (GALLONS)

Ref. (2)

Waste Type: Purex

Tank No.

$\begin{array}{lll}1 \mathrm{~F} & 7.0 \mathrm{E} 3 & \\ 2 \mathrm{~F}^{*} & 4.03 \mathrm{E} & \\ 3 \mathrm{~F} & 4.0 \mathrm{E} 3 & \\ 4 \mathrm{~F}^{*} & 1.3 \mathrm{E} 5 & \\ 5 \mathrm{~F}^{*} & 4.1 \mathrm{E} 4 & \\ 6 \mathrm{~F}^{*} & 2.5 \mathrm{E} 4 & \\ 7 \mathrm{~F}^{*} & 8.1 \mathrm{E} 4 & 1.4 \mathrm{E} 5 \\ 8 \mathrm{~F}^{*} & & 2.4 \mathrm{E} 5 \\ 17 \mathrm{~F}^{*} & & 3.4 \mathrm{E} 5 \\ 18 \mathrm{~F}^{*} & & 2.7 \mathrm{E} 5 \\ 19 \mathrm{~F}^{*} & & 2.5 \mathrm{E} 4 \\ 20 \mathrm{~F} & & 1.0 \mathrm{E} 4 \\ 25 \mathrm{~F} & & \\ 26 \mathrm{~F} & & 1.5 \mathrm{E} 5\end{array}$

\section{2. $4 \mathrm{E} 4$}

4. $4 \mathrm{E} 4$

NOT IN SERVICE

LAW

$34 \mathrm{~F}$

$44 \mathrm{~F}$

$45 \mathrm{~F}$

$46 \mathrm{~F}$
Purex HM HM

HAW

LAW

otal

Sludge

Salt

7.0Е3 $\quad 4.3 \mathrm{E} 5$

4.0E3 4.5E5

$4.0 \mathrm{E} 3 \quad 4.3 \mathrm{E} 5$

$1.3 \mathrm{E} 5 \quad 3.4 \mathrm{E} 4$

4. $1 \mathrm{E} 4$

$2.5 \mathrm{E} 4$

SiO2,C

2.2E5

2. $4 \mathrm{E} 5$

$47 \mathrm{~F}$

* = sludge sampled and analyzed.
$3.4 \mathrm{E} 5$

2.7E5

2. $5 \mathrm{E} 4$

1. $0 \mathrm{E} 4$

$1.5 \mathrm{E} 5$

zeolite

2. $4 \mathrm{E} 4$

4. $4 \mathrm{E} 4$

1.3E5

100 Area

1. $3 E 5$

3. $8 \mathrm{E} 5$

2.0E4

$3.7 \mathrm{E} 5$

4. $0 \mathrm{E} 5$

1.1E5

$9.2 \mathrm{E} 5$

$5.3 \mathrm{E} 5$

$1.7 \mathrm{E} 5$

4. $9 \mathrm{E} 5$

$1.5 \mathrm{E} 5$

2. 4E5 
TABLE II

SLUDGE IN H-AREA WASTE TANKS

WASTE VOLUME (GALLONS). Ref. (2)

Waste Type

Purex Purex HM HM

LAW

HAW

LAW

other

Total

Sludge

Salt

Tank No.

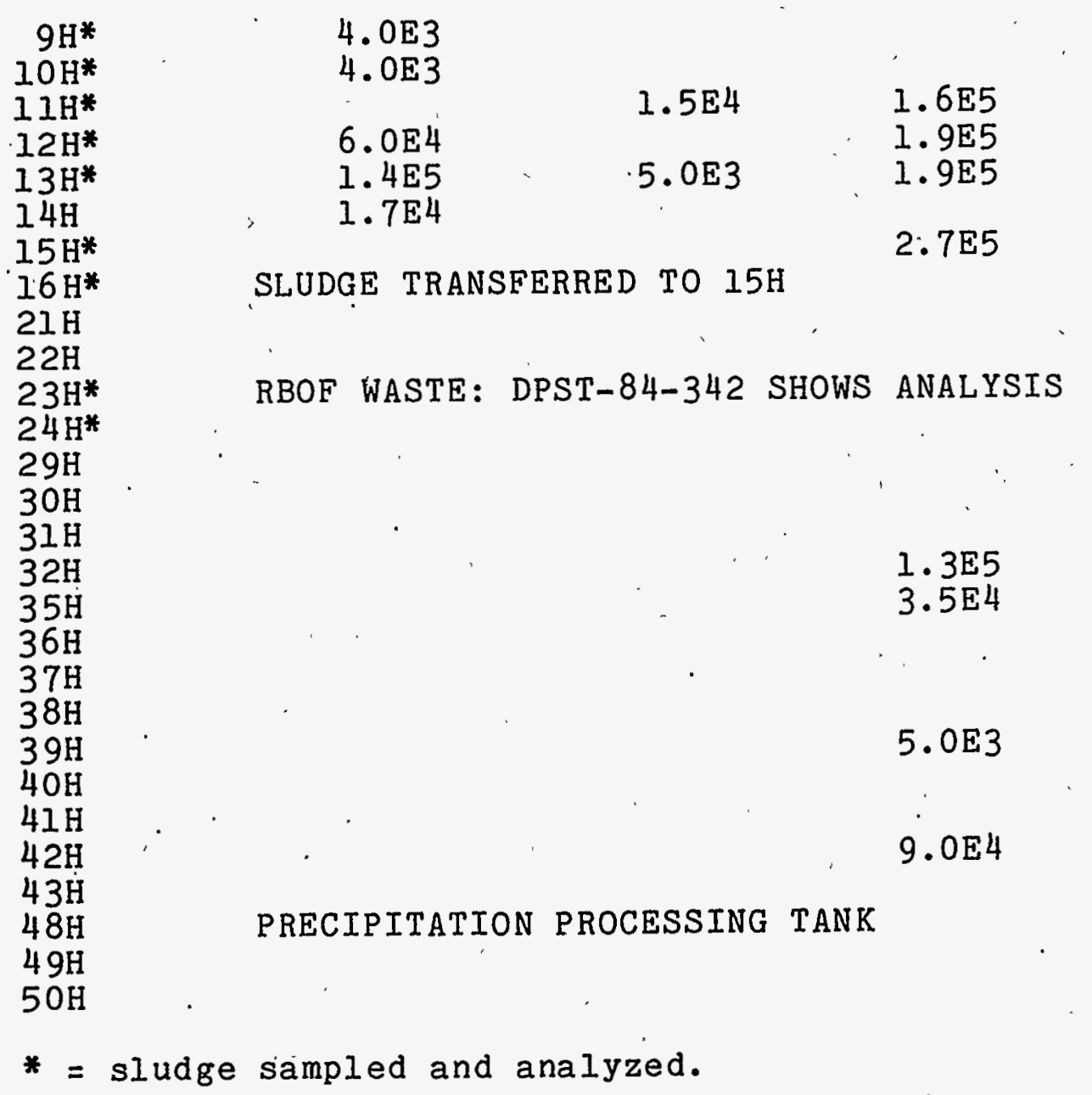

5. OE3

$6.8 \mathrm{E} 4$

1. $0 \mathrm{E} 4$

4. 0E3

2. $2 \mathrm{E} 5$

$5.3 \mathrm{E} 4$

4. 3E4

zeolite

4. $0 \mathrm{E} 3$

4. OE 3

1. 8E5

$2.5 \mathrm{E} 5$

4. $0 \mathrm{E} 5$

2.7E4

2.7E5

2. $2 \mathrm{E} 5$

$5.3 \mathrm{E} 4$

4. $3 E 4$

1. 3E 5

$3.5 \mathrm{E} 4$

1. $0 \mathrm{E} 6$

$6.0 \mathrm{E} 3$

9. $6 \mathrm{E} 5$

3. $6 \mathrm{E} 5$

3.IE5

$5.0 \mathrm{E} 3$

2. $4 E 4$

zeolite

$9.0 \mathrm{E} 4$

$2.4 E 4$

8. $4 E 4$ 


\section{MERCURIC OXIDE IN SLUDGE SAMPLES}

Tank No.

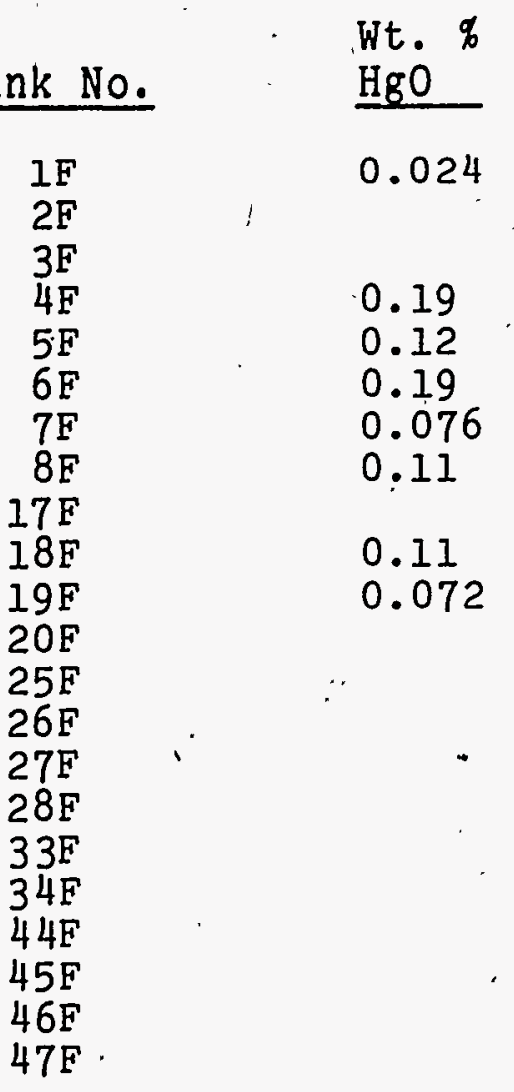

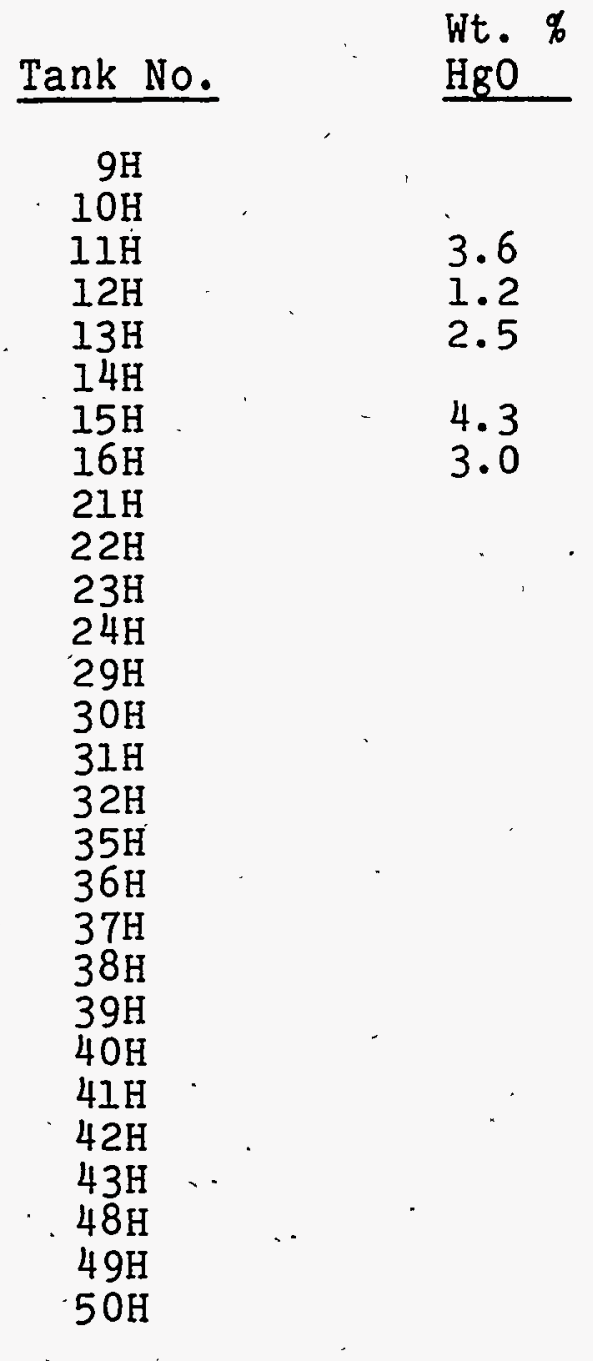

NOTE: Results for tanks $I F$ and $19 F$ are on insoluble residue from salt samples. 
TABLE IV

SLUDGE COMFOSITION EY WASTE TYPE

(WT $\%$ OF EACH SFECIES)

Ref (1).

51 udge

ADJUSTED*

\section{species \\ $======$}

FE $(\mathrm{OH})=$

14 ma?

UD2 (OH) 2

A1 (ㅁH) 3

CaCO.

$\mathrm{CaS04}$

$\mathrm{CaC2D4}$

$\mathrm{C}=$ (FO4) 2

CaF2

Ni. $(\mathrm{OH}) 2$

NaCH

NaNOS

$\mathrm{HgO}$

NaCl

NaI

Fiulo2

Si. 92

ThO2

Ea 004

$\mathrm{CE}(\mathrm{OH}) \mathrm{\Xi}$

Fb304.

La $(\mathrm{OH}) \equiv$

$\mathrm{ZrO}(\mathrm{OH}) \mathrm{Z}$

Cr (OH) 3

$\mathrm{AgOH}$

CUI (OH) 2

$\mathrm{Co}(\mathrm{OH}) \equiv$

$F r(\mathrm{OH}) \equiv$

$\mathrm{Zn}(\mathrm{OH}) \mathrm{Z}$

Mg $(O H) 2$

COAL

ZEOL ITE

FNOS

Na2504

FOH

SiCO:

BaCOS

FoCOE

Na2C204

NajOPO4.

NaF

GAND
FUFEX HAW FUFEX LAW
$===============$

43.51

12. 11

10.73

6.50

2.77

0.00

0.00

0.51

0.04

5.79

5.08

1.34

0.24

0.21

0.00

0.30

0.75

0.08

0.80

0.26

0.11

0. 12

0.60

(). 59

0.07

0.15

0.00

0. 12

0. 25

0.58

0.00

0. 00

0. 25

0. 010

0.00

0. 27

0.00

0.49

0.00

0.00

0.00

0.0

100.01
46.52

4.08

7.55

1.46

5. 28

0.65

0.00

). 19

(j) . 3

$\therefore-4$

4. 55

1,52

0.07

2. 01

0.04

i). 66

1. 8

0.01

0. $\exists 0$

a. \pm 4

0. .77

0.21 .

0.79

0. 42

0. 55

0. 2

0.02

0. 21

0.46

0. 20

0. 50

2.36

0.85

0.00

0.00

o. 11

$\theta 00$

0.09

0.00

o. 08

0.00

o. 42
HN HAW

FUFEX LAW

48.90

4. 21

7.79

13.99

5. 45

0.67

0.00

(). 20

0.74

3.45

4. 69

1. .57

0.07

2. 07

0.04

0.69

1. 89

0.01

$0 . \pm 1$

0.55

0.50

6. 22

0.80

0.45

0. \pm 6

0. 24

0.02

0.22

0. 47

0. 21

0.00

0. 00

6. 80

0.00

0.00

). 11

0. 00

0.00

0. 00

0.00

0.00

0.00

100.02

100.01
$======$

10.19

2.61

1. 25

67.06

0.00

0.00

2.16

0.09

0.00

1.01

1.35

3.26 .

5.01

0.00

0.00

0.05

4.68

1. 31

0.14

0.05

0.01

0.04

0.25

0.23

0.00

0.05

0.00

0.04

0.05

0.27

0.00

0.00

0.22

0.32

0.00

0.06

0.00

0.00

0.00

0.05

0.24

0.00

100.00
HW LAW

$======$

5.5. 54

9.15

$\because .64$

15.95

$\because 52$

0.00

6. 00

0.00

0.00

a. 52

2.54

(). 27

1. 66

1. 11

0.00

0.00

0.00

0.08

0.17

0.92

0.44

0.28

0.42

0.12

0.00

0.03

0.00

0.18

0.00

0.47

0.00

22.78

0.14

0.00

0.00

0.05

0.00

0.05

0.00

0.00

0.00

0.00

100.01

100.01

HM LAW

$==== \pm=$

45.02

11.85

4.71

20.63

ADJUSTED* 
TABLE $V-1$

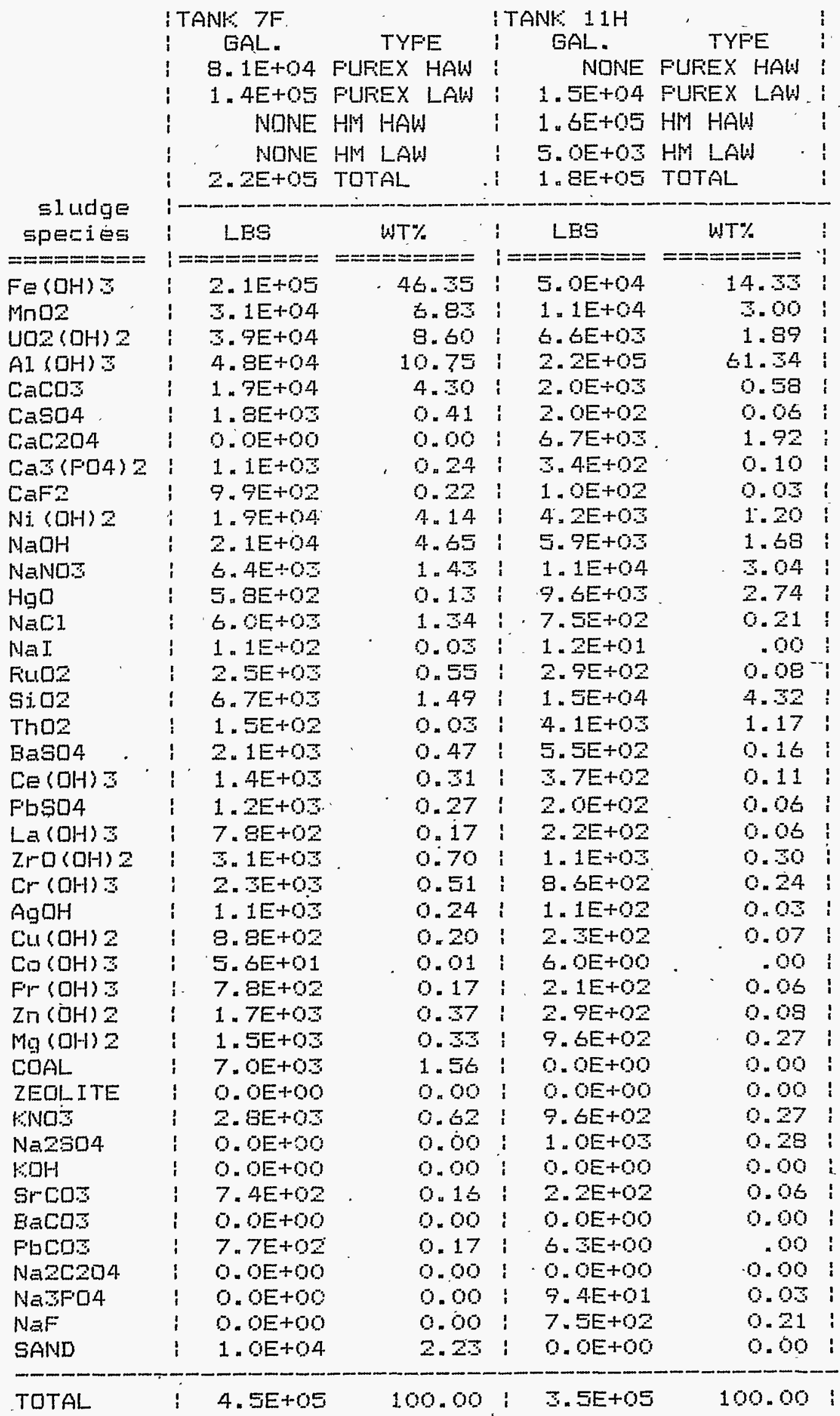


TAELE $V-2$

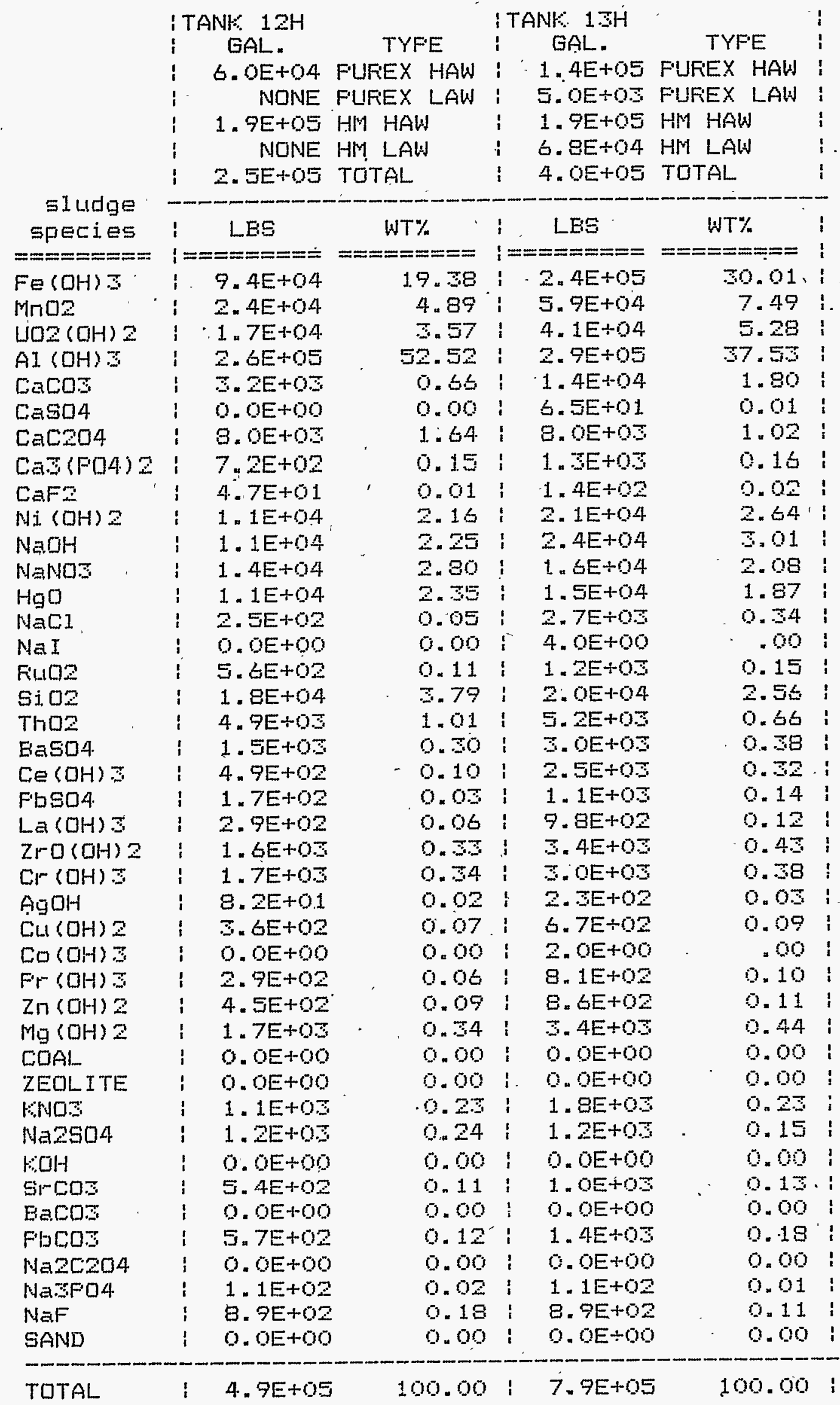


TAELE $V-3$

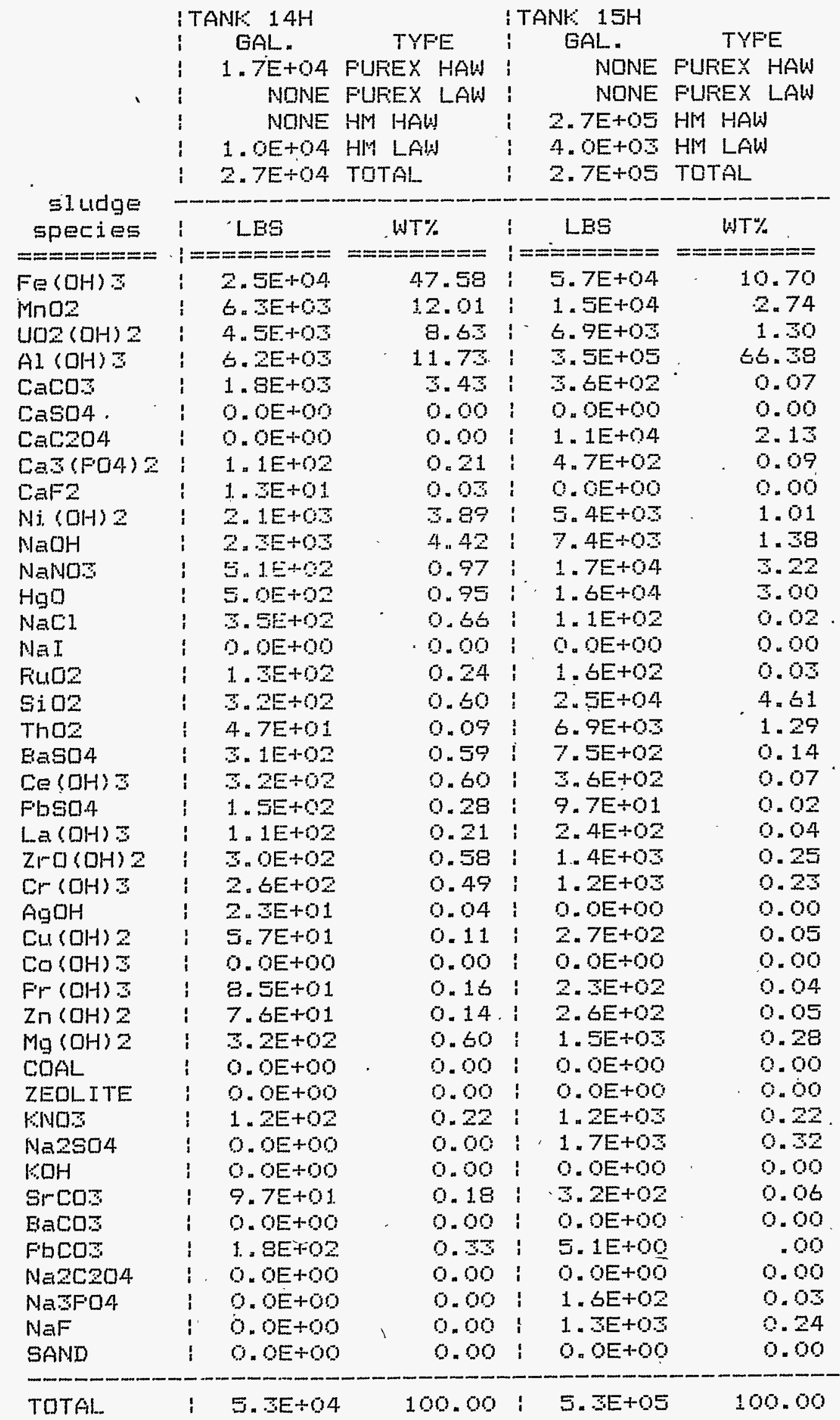


TABLE VI

SLUDGE BATCHES FOR FEED TO THE DWPF SLUDGE PLANT Ref (3)

\begin{tabular}{|c|c|c|c|c|c|}
\hline $\begin{array}{l}\text { Batch } \\
\text { Number }\end{array}$ & $\begin{array}{l}\text { Tank } \\
\text { Number }\end{array}$ & $\begin{array}{l}\text { Waste } \\
\text { Type }\end{array}$ & $\begin{array}{l}\text { Waste } \\
\text { Age } \\
\end{array}$ & $\begin{array}{l}\text { Waste } \\
\text { Volume }\end{array}$ & $\begin{array}{l}\text { Cumulati } \\
\text { Volume }\end{array}$ \\
\hline & $\begin{array}{l}18 \mathrm{~F} \\
21,22 \mathrm{H} \\
42 \mathrm{H} \\
19 \mathrm{~F}\end{array}$ & $\begin{array}{l}\text { P-LAW } \\
\text { HM-LAW } \\
\text { HM-HAW } \\
\text { ZEO. }\end{array}$ & $\begin{array}{l}16 Y \\
13 Y \\
25 Y \\
-\end{array}$ & $\begin{array}{c}227,000 \\
311,000 \\
91,000 \\
?\end{array}$ & $\begin{array}{l}227,000 \\
538,000 \\
629,000 \\
629,000\end{array}$ \\
\hline
\end{tabular}

$2 a$

$\begin{array}{llccc}18 \mathrm{~F} & \text { P-LAW } & 18 Y & 410,000 & 410,000 \\ 15 \mathrm{H} & \text { HM-HAW } & 27 \mathrm{Y} & 269,000 & 544,500 \\ 11 \mathrm{H} & \text { HM-HAW } & 20 \mathrm{Y} & 176,000 & 632,500 \\ 14 \mathrm{H} & \text { HM-HAW } & 35 \mathrm{Y} & 27,000 & 646,000 \\ 19 \mathrm{~F} & \text { ZEO. } & --- & ? & 646,000\end{array}$

$3 a$

$12 \mathrm{H}$
$5 \mathrm{~F}$
$6 \mathrm{~F}$
$7 \mathrm{~F}$
$7 \mathrm{~F}$
$8 \mathrm{~F}$
$8 \mathrm{~F}$
$8 \mathrm{~F}$

$\begin{array}{ll}\text { HM-HAW } & 27 Y \\ \text { P-HAW } & 32 Y \\ \text { P-HAW } & 27 Y \\ \text { P-HAW } & 39 Y \\ \text { P-LAW } & 3 I Y \\ \text { P-HAW } & 24 Y \\ \text { P-LAW } & 37 Y \\ \text { P-LAW } & 15 Y\end{array}$

$$
\begin{array}{r}
253,000 \\
41,000 \\
25,000 \\
175,000 \\
46,000 \\
118,000 \\
59,000 \\
59,000
\end{array}
$$$$
126,500
$$$$
167,500
$$$$
192,500
$$$$
367,500
$$$$
413,500
$$$$
531,500
$$$$
590,500
$$

Year Fed to DWPF

89-90

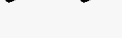

93-94

$95-96$

$\begin{array}{llrrr}4 \mathrm{~F} & \text { P-HAW } & 26 \mathrm{Y} & 127,000 & 127,000 \\ 13 \mathrm{H} & \text { P-HAW } & 40 \mathrm{Y} & 175,000 & 258,250 \\ 13 \mathrm{H} & \text { P-HAW } & 41 \mathrm{Y} & 40,000 & 288,250 \\ 13 \mathrm{H} & \text { HM-HAW } & 32 \mathrm{Y} & 80,000 & 348,250 \\ 13 \mathrm{H} & \text { HM-LAW } & 33 \mathrm{Y} & 108,000 & 429,250 \\ 26 \mathrm{~F} & \text { P-LAW } & >5 \mathrm{Y} & 200,000 & 629,250 \\ 24 \mathrm{H} & \text { ZEO. } & --- & ? & 629,250\end{array}$


COMPARISON OF DWPF FEED BATCHES TO OVERALL BLEND

\begin{tabular}{|c|c|c|c|c|c|}
\hline $\begin{array}{l}\text { Sludge } \\
\text { Species }\end{array}$ & $\begin{array}{l}\text { Batch la } \\
\text { (wt\%) }\end{array}$ & $\begin{array}{l}\text { Batch 2a } \\
\text { (wto) } \\
\end{array}$ & $\begin{array}{l}\text { Batch } 3 a^{*} \\
(w t \%)\end{array}$ & $\begin{array}{c}\text { Batch } 4 a \\
(\text { wt\%) } \\
\end{array}$ & $\begin{array}{l}\text { Blend** } \\
(w t \%)\end{array}$ \\
\hline $\begin{array}{l}\mathrm{Fe}(\mathrm{OH}) 3 \\
\mathrm{MnO} 2 \\
\mathrm{UO} 2(\mathrm{OH}) 2 \\
\mathrm{Al}(\mathrm{OH}) 3 \\
\mathrm{CaCO} 3 \\
\mathrm{CaF} 2 \\
\mathrm{Ni}(\mathrm{OH}) 2 \\
\mathrm{NaOH} \\
\mathrm{NaNO} 3 \\
\mathrm{Na} 2 \mathrm{SO} 4 \\
\mathrm{NaF} \\
\mathrm{NaCl} \\
\mathrm{NaI} \\
\mathrm{HgO} \\
\mathrm{RuO2} \\
\mathrm{SiO} 2 \\
\mathrm{Coal} \\
\mathrm{Zeolite} \\
\text { Other }\end{array}$ & $\begin{array}{r}42.68 \\
8.07 \\
5.46 \\
19.92 \\
4.19 \\
0.12 \\
1.86 \\
3.68 \\
1.67 \\
0.09 \\
0.07 \\
1.45 \\
0.01 \\
1.95 \\
0.25 \\
2.03 \\
0 \\
0.81 \\
5.68\end{array}$ & $\begin{array}{r}37.49 \\
4.53 \\
5.79 \\
20.88 \\
3.42 \\
0.21 \\
2.90 \\
3.93 \\
3.35 \\
0.23 \\
0.17 \\
1.30 \\
0.03 \\
2.23 \\
0.45 \\
4.58 \\
0 \\
1.18 \\
7.33\end{array}$ & $\begin{array}{r}42.33 \\
8.66 \\
8.38 \\
13.50 \\
2.87 \\
0.11 \\
4.41 \\
4.46 \\
2.38 \\
0.13 \\
0.09 \\
0.63 \\
0.01 \\
1.32 \\
0.39 \\
2.81 \\
0.54 \\
0 \\
6.99\end{array}$ & $\begin{array}{r}41.90 \\
7.89 \\
7.56 \\
12.59 \\
3.43 \\
0.13 \\
3.62 \\
4.14 \\
1.66 \\
0.06 \\
0.04 \\
0.95 \\
0.01 \\
0.91 \\
0.38 \\
1.83 \\
0 \\
7.54 \\
5.35\end{array}$ & $\begin{array}{r}39.89 \\
6.84 \\
6.63 \\
16.46 \\
3.38 \\
0.15 \\
3.16 \\
3.98 \\
2.34 \\
0.14 \\
0.10 \\
1.07 \\
0.02 \\
1.60 \\
0.37 \\
2.94 \\
0.13 \\
4.50 \\
6.30\end{array}$ \\
\hline Total & 100.00 & 100.00 & 100.00 & 100.00 & 100.00 \\
\hline $\begin{array}{l}\text { Gallons } \\
\text { of Feed }\end{array}$ & 629,000 & 646,000 & 649,000 & 629,000 & \\
\hline $\begin{array}{l}\text { F-Area } \\
\text { Tanks }\end{array}$ & 18 & 18 & $\therefore \quad 5,6,7,8$ & 4,26 & \\
\hline $\begin{array}{l}\text { H-Area } \\
\text { Tanks }\end{array}$ & $21,22,42$ & $11,14,15$ & 12 & 13 & \\
\hline
\end{tabular}

*Includes sludge from Tank $7 \mathrm{~F}$ **After DPST-83-313 